\title{
The Association between Nutritional Status and Iron Status in Students of Junior High School of 39 Kerinci Regency Jambi Province In 2020
}

\author{
Zeffira $L^{1}$, Pitra DAH ${ }^{2}$, Saputra $E^{3}$ \\ ${ }^{1}$ Lecturer at the Faculty of Medicine, Baiturrahmah University, Padang, Indonesia \\ ${ }^{2}$ Lecturer of the Faculty of Medicine, Baiturrahmah University, Padang, Indonesia \\ ${ }^{3}$ Medical Student of Baiturrahmah University, Padang, Indonesia \\ E-Mail: Lazheplus@Gmail.Com
}

\section{$\underline{\text { Abstract }}$}

Background: Nutrition is one of determining factor for the quality of human resources. Nutritional problems can be in the form of excess nutrition (obesity) or malnutrition. A person's nutritional status depends on nutritional intake and needs.

Objective: To determine the association between nutritional status and iron status in students of Junior High School of 39 Kerinci Regency Jambi Province in 2020.

Method: It was an associative analytic with cross-sectional approach. The were 25 students recruited using the total sampling technique. Univariate data analysis was presented in the form of frequency distribution and percentage and bivariate analysis using the chi-square test and data processing using the computerized SPSS version 25.0 program.

Result: there was an association between nutritional status and iron status in students of Junior High School of 39 Kerinci Regency Jambi Province in 2020 ( $\mathrm{p}=0.029$ ).

Conclusion: there was an association between nutritional status and iron status in students Junior High School of 39 Kerinci Regency Jambi Province

Keywords: Nutritional Status of Iron Status, And Iron Deficiency Anemia

\section{Introduction:}

Anemia is the one of main health problems in the world, especially in developing countries, an estimated $30 \%$ of the world population suffer from anemia. Anemia is common in adolescents, especially in adolescent girls. The prevalence of anemia in the world ranges from $40-88 \%$, according to the World Health Organization (WHO 2013). Data from Riskesdas 2013 results, the prevalence of anemia in Indonesia is $21.7 \%$, patients with anemia aged 5-14 years are $37.1 \%$ and $18.4 \%$ are patients aged 15-24 years (Kemenkes RI, 2014). Data from the Household Health Survey (SKRT) in 2012 stated that the prevalence of anemia in children under five was $40.5 \%$, pregnant women was $50.5 \%$, postpartum mothers were $45.1 \%$, teenage girls aged 10-18 years were $57.1 \%$ and age $19-45$ years by $39.5 \%$.
Women have the highest risk of developing anemia, especially in adolescent girls ${ }^{1}$. Anemia in young women in Indonesia has increased from $37.1 \%$ in Riskesdas 2013 to $48.9 \%$ in Riskesdas 2018. In young women, anemia that occurs is still relatively high, around $40-88 \%$ of young women in the world suffer from anemia. ${ }^{1,2,4,5}$

The prevalence of anemia in adolescent girls in Jambi province in 2014 was $78.7 \%$ with the main cause being the lack of habit of eating foods containing iron. The prevalence of anemia in adolescents in Jambi province in 2015 of all adolescents recorded was $67 \%$ with the main cause being the lack of breakfast. ${ }^{12}$

Anemia is a condition when the hemoglobin (HB) in the blood is low, in adolescents it is said to be low when the hemoglobin level is $(<12 \mathrm{~g} / \mathrm{dl})$. Anemia can be caused by various causes such as 
folic acid deficiency, vitamin A deficiency, vitamin B12 deficiency, and iron deficiency. ${ }^{1,2,4,5,7}$ Iron deficiency anemia (ADB) is a health problem that often occurs in children throughout the world, especially in developing countries including Indonesia. This disease is caused by a lack of iron in the patient's body. Patients with iron deficiency anemia in the entire population in the world, namely $30 \%$ of the world's population suffer from iron deficiency anemia, most of these percentages are in developing countries. ${ }^{3.15}$

Iron is an important mineral for the body. This substance is needed in the formation of blood, namely in the synthesis of hemoglobin. Iron also plays an important role in hemoglobin, namely as a means of transporting oxygen from lung tissue to tissues throughout the body. This substance is widely found in food, but many people in the world, including Indonesia, experience iron deficiency. $3,15,24$

The main function of iron is for the development of the nervous system, which is needed in the myelination process, neurotransmitters, dendritogenesis, and nerve metabolism. Iron deficiency is very influential on cognitive function, behavior, and growth of a person, especially infants. Iron is a source of energy for muscles so that it affects physical endurance and work ability, especially in adolescents. If the occurrence of iron deficiency during pregnancy will increase the risk of perinatal and infant mortality. ${ }^{3.15}$

Adolescence is a transition from childhood to adulthood, which includes all developments experienced in preparation for entering adulthood. This age group is important because it becomes a process between a free childhood to an adult that demands responsibility. ${ }^{1}$

Adolescence is a period that requires more nutrients because optimal nutritional intake is very influential on the growth and development of the body. Nutrition is a metabolic process through which food is consumed normally through digestion, absorption, transport, storage, metabolism, and expenditure of substances that are not used to maintain growth and produce energy. ${ }^{3}$

Malnutrition is a health problem that is common in teenagers that cause anemia should get special attention. The government's efforts to overcome these problems have shown that nutritional adequacy is obtained from the suitability (amount and type) of food consumed, with the needs of body functions so that it is beneficial and optimally maintained. ${ }^{1.5}$

Iron status is a condition caused by the amount of iron in the blood. The normal amount of iron in the body is more than 4 grams. The characteristics of iron status are divided into 3, namely, normal (no anemia, not iron deficiency), not iron deficiency anemia (stage 1 and/or stage 2 iron deficiency, and iron deficiency anemia (late stage iron deficiency). Previous studies have shown the prevalence of iron deficiency anemia Iron deficiency for adolescent girls in Jambi province was $78.8 \%$ in 2014 . The prevalence of anemia in all adolescent boys and girls recorded in Jambi province was $67 \%$ in 2015. This shows the incidence of iron deficiency anemia in adolescents in the province Jambi is still very high ${ }^{24.25}$

Nutrition is a determining factor for the quality of human resources. Nutritional problems can be in the form of excess nutrition (obesity) or undernutrition. A person's nutritional status depends on nutritional intake and needs, if between nutritional intake and nutritional needs in the body balanced, it will produce good nutrition. The nutritional intake needs of each individual is different, this depends on age, sex, active size, weight, and height. When a person's condition is nutritionally deficient or his nutrition is below average, then the nutritional status is categorized as undernourished. ${ }^{5.6}$

Yuli Suryanti's research on the relationship between knowledge and diet with the incidence of anemia in adolescent girls at the private MTs Alhidayah Talang Bakung in Jambi city in 2017 showed the results of students' descriptions based on eating patterns on the incidence of anemia with a sample of 84 students, obtained students with eating patterns. There were $37(44.0 \%)$ students who were not good and there were $25(29.8 \%)$ students who had anemia. Based on the results of the study, it was found that $19(51.4 \%)$ students with poor eating patterns had anemia. ${ }^{29}$

Putri Azzaroh's research in 2018 on factors related to the incidence of anemia in adolescent girls at Senior High School of 2 (SMU 2) in Jambi city with 88 students as respondents, of the 25 students whose knowledge about the incidence of anemia was not good, 18 students $(72.0 \%)$ had anemia. ${ }^{30}$ Safitri's research in 2019 on the relationship of nutritional knowledge to the incidence of anemia in adolescent girls at Junior High School of 13 
(SMPN 13) Jambi city with a sample of 50 students, as many as 22 students who have poor knowledge, 10 students $(45 \%)$ experience anemia. $^{31}$

The results of a survey in the Kerinci Regency area of Jambi Province, researchers chose SMPN 39 Kerinci Regency Jambi Province in the Bukit Kerman Health Center work area, precisely in the village of Pondok Pulau Sangkar, namely because the village is $88 \%$ of the population in the village of Pondok Pulau Sangkar classified as underprivileged. This is due to the lack of employment opportunities for the residents of Pondok Pulau Sangkar village. The average income of the residents of Pondok Pulau Sangkar village comes from farm laborers with an income of Rp. 50,000. Residents earn only if they get job offers from garden owners. This is not every day obtained by the average resident of Pondok Pulau Sangkar village because the number of poor people is more than residents who have gardens that offer jobs. In addition, basic needs must be met such as housing, clothing, children's school supplies, and eating nutritious food. This causes most children to teenagers to be at risk of experiencing malnutrition (Bukit Kerman subdistrict data). ${ }^{28}$

Based on the description above, complete blood tests and nutritional status checks are very important to do in order to determine the association between nutritional status and iron status in students of SMPN 39 Kerinci Regency, Jambi Province in 2020 in order to take immediate action to prevent and manage malnutrition and iron deficiency anemia. on Student SMPN 39 Kerinci District, Jambi Province, 2020.

\section{Research Methods:}

This research was conducted at SMPN 39, Kerinci Regency, Jambi Province, from December 2020 to January 2021. The type of research used in this study was associative analytic with a cross sectional approach. The data collection was taken directly from the students of SMPN 39 Kerinci Regency, Jambi Province in 2020. The target population used in this study was all students of SMPN 39 Kerinci Regency, Jambi Province, 2020. The affordable population used in this study were all students of SMPN 39 Kerinci Regency, Jambi Province. year 2020. The sampling method was selected using a total sampling technique with 25 patients. Data that is analyzed is univariate analysis aims to see the variation of each variable studied and is used to determine the frequency distribution of the independent variable (nutritional status) and the dependent variable (iron status). Bivariate analysis is an analysis made to see the association between the independent variable and the dependent variable by using statistical tests, chi-square test. The association is said to be significant if $\mathrm{p}<0.05$ with a rejection degree of $5 \%(p=0.05)$.

\section{RESEARCH RESULTS:}

Based on the research that has been carried out aimed at knowing the relationship between nutritional status and iron status in students of SMPN 39 Kerinci Regency Jambi Province in 2020 on 25 respondents, the authors can describe the results of the research in the exposure below:

\section{Characteristics of Respondents}

Age

The results obtained distribution age frequency can be described as follows:

Table 1 Age Frequency Distribution At Smpn 39 Kerinci Regency, Jambi Province Year 2020

\begin{tabular}{|c|c|c|}
\hline Age & $\boldsymbol{f}$ & $\boldsymbol{\%}$ \\
\hline $12.0-12.11$ years & 8 & 32.0 \\
\hline $13.0-13.11$ years & 7 & 28.0 \\
\hline $140.0-14.11$ years & 4 & 16.0 \\
\hline$>14$ years & 6 & 24.0 \\
\hline Total & 25 & 100.0 \\
\hline
\end{tabular}

Based on table 1, it is found that from 25 respondents, the most aged 12.0-12.11 years are 8 people $(32.0 \%)$.

\section{Gender}

The results of the study found that the sex frequency distribution can be described as follows:

Table 2 frequency distribution of the sex of the respondents in smpn 39 kerinci regency, jambi province year 2020

\begin{tabular}{|l|l|c|}
\hline \multicolumn{1}{|c|}{ Gender } & $\boldsymbol{f}$ & $\boldsymbol{\%}$ \\
\hline Male & 11 & 44.0 \\
\hline Female & 14 & 56.0 \\
\hline Total & 25 & 100,0 \\
\hline
\end{tabular}

Based on table 2, it is found that out of 25 respondents, the most are female, namely 14 people $(56.0 \%)$.

\section{Univariate Analysis of Iron Status}

The results showed that the frequency distribution of iron status can be described as follows: 
Table 3 frequency distribution of respondent iron status in smpn 39 kerinci regency, jambi province year 2020

\begin{tabular}{|l|c|c|}
\hline \multicolumn{1}{|c|}{ Iron Status } & $\boldsymbol{F}$ & $\boldsymbol{\%}$ \\
\hline No Iron Deficiency & 11 & 44.0 \\
\hline Iron Deficiency Without Anemia & 11 & 44.0 \\
\hline Iron Deficiency Anemia & 3 & 12.0 \\
\hline Total & 25 & 100.0 \\
\hline
\end{tabular}

Based on table 3, it was found that out of 25 respondents, 11 people had iron deficiency without anemia (44\%).

\section{Stages of Iron Deficiency}

The results showed that the frequency distribution of the stages of iron deficiency can be described as follows:

Table 4 frequency distribution of iron deficiency stages respondent at smpn 39 kerinci district, jambi province year 2020

\begin{tabular}{|c|c|c|}
\hline Stages of Iron Deficiency & $f$ & $\%$ \\
\hline No Iron Deficiency & 11 & 44.0 \\
\hline Stages 1 (Iron Depletion) & 10 & 40.0 \\
\hline Stage 2 (Iron Limited Erythropoiesis) & 1 & 4.0 \\
\hline Stage 3 (Iron Deficiency Anemia) & 3 & 12.0 \\
\hline Total & 25 & 100.0 \\
\hline
\end{tabular}

Based on table 4, it was found that out of 25 respondents, at most not iron deficiency namely 11 people $(44.0 \%)$ and as many as (40\%) are in stage 1 (Iron Depletion).

\section{Nutritional Status}

The results showed that the frequency distribution of nutritional status can be described as follows:

Table 5 frequency distribution of respondent nutrition status at smpn 39 kerinci regency, jambi province year 2020

\begin{tabular}{|l|c|c|}
\hline Nutritional Status & $\boldsymbol{f}$ & $\boldsymbol{\%}$ \\
\hline Normal & 9 & 36.0 \\
\hline Less Total & 16 & 64.0 \\
\hline \multicolumn{2}{|c|}{25} & 100.0 \\
\hline
\end{tabular}

Based on Table 5 shows that of the 25 respondents, the most with poor nutritional status are 16 people $(64.0 \%)$.

\section{Bivariate analysis}

The results showed that the association between nutritional status and iron status in students of SMPN 39 Kerinci Regency, Jambi Province in 2020 can be described as follows:
Table 6 Association of nutritional status and iron status in students of smpn 39 Kerinci Regency, Jambi province year 2020

\begin{tabular}{|c|c|c|c|c|c|c|c|}
\hline \multirow{3}{*}{ Iron } & \multicolumn{4}{|c|}{$\begin{array}{c}\text { Status Status } \\
\text { Nutrition }\end{array}$} & \multicolumn{2}{|c|}{ Total } & \multirow{2}{*}{$\begin{array}{c}\mathbf{p} \\
\text { value }\end{array}$} \\
\hline & \multicolumn{2}{|c|}{ Normal } & \multicolumn{2}{|c|}{ Less } & & & \\
\hline & $f$ & $\%$ & $f$ & $\%$ & $n$ & $\%$ & \\
\hline $\begin{array}{l}\text { No Iron } \\
\text { Deficiency }\end{array}$ & 7 & $\begin{array}{c}63 . \\
6\end{array}$ & 4 & 36.4 & $\begin{array}{l}1 \\
1\end{array}$ & 100 & \\
\hline $\begin{array}{l}\text { Iron } \\
\text { Deficiency } \\
\text { Without } \\
\text { Anemia }\end{array}$ & 1 & 9.1 & $\begin{array}{l}1 \\
0\end{array}$ & 90.9 & $\begin{array}{l}1 \\
1\end{array}$ & 100 & 0.029 \\
\hline $\begin{array}{l}\text { Iron } \\
\text { Deficiency } \\
\text { Anemia }\end{array}$ & 1 & $\begin{array}{c}33 . \\
3\end{array}$ & 2 & $\begin{array}{c}66 \\
7\end{array}$ & 3 & 100 & \\
\hline Total & 9 & $\begin{array}{c}36 . \\
0\end{array}$ & $\begin{array}{l}1 \\
6\end{array}$ & 64.0 & $\begin{array}{l}2 \\
5\end{array}$ & 100 & \\
\hline
\end{tabular}

Based on table 6 it was found that respondents with iron status without iron deficiency had the most normal nutritional status, namely 7 people $(63.6 \%)$, in the category of iron deficiency without anemia the most have less nutrition, namely 10 people $(90.9 \%)$ and in the category of iron deficiency anemia the most have less nutrition, namely 2 people (66.7\%). The results of the statistical test (chi-square) obtained a value of $\mathrm{p}=0.029(\mathrm{p}<0.05)$, it can be concluded that there is an association between nutritional status and iron status in students of SMPN 39 Kerinci Regency, Jambi Province in 2020.

\section{DISCUSSION:}

Age

Based on the results obtained from 25 respondents, the most age was 12.0-12.11 years, namely 8 people $(32 \%)$ and at the age of 11 years, 12 years and 13 years, the percentages were not much different. Based on the age division above, the maximum age is 12.0-12.11 years in students at SMPN 39 Kerinci Regency, Jambi Province in 2020. The results of this study are in line with previous research conducted by Azis, (2018), the highest student ages were 12 and 13 years old $(32.37 \%) .^{32}$ and Syahfitri's research, (2017) obtained that the age of the most patients was 12 years, namely $(36 \%){ }^{33}$

Research respondents in this age range are included in the early and middle adolescence, at this time the growth in height and weight takes place rapidly. Adolescent girls experience a faster 
growth rate than boys because their bodies need preparation before reproductive age, while boys experience a growth spurt two years later. ${ }^{33}$

Individual energy needs are adjusted to age and activity level, if there is a lack of energy, one's work productivity tends to decrease, where a person will be lazy to work and tend to work more slowly. As you get older, your body's need for energy will also increase. Energy is needed to support the increasing and increasing variety of physical activities. ${ }^{33}$

\section{Gender}

Based on the research, it was found that the most gender was female, namely 14 people (56\%). From this description, it was found that the highest gender was female in students at SMPN 39 Kerinci Regency, Jambi Province in 2020. The results of this study are in line with previous research conducted by Syahfitri, (2017) obtained that the most gender is female $(66 \%) .{ }^{33}$ and the results of this study are in line with previous research conducted by Azis, (2018), it was found that the gender of the most respondents was also female, namely (55.7\%).

There are more women than men in this study. Based on student absenteeism at SMPN 39, Kerinci Regency, Jambi Province, data shows that the number of male students is more than female students, so the sample opportunity is greater for women than men.

The nutritional needs of men and women tend to be different due to different physical activities. This is in accordance with the previous theory that boys have more active activities than girls. Where the energy released by boys is more than girls who are not too active in playing. ${ }^{34}$

\section{Iron status}

Based on the research results obtained from 25 respondents, the iron status in the category of not iron deficiency and iron deficiency without anemia were 11 people (44\%) and iron deficiency anemia were 3 people (12\%) in students at SMPN 39 Kerinci Regency, Jambi Province in 2020. The results of this study are supported by previous research conducted by Tiastuti, (2016), of which $(65.1 \%)$ of respondents with iron deficiency iron status without anemia and also Kusudaryati's research, (2018) obtained as many as $(88,9 \%)$ respondents with iron status in the non-iron deficiency category. ${ }^{35,36}$
Iron deficiency can result in low levels of hemoglobin in the blood, so that the oxygen needed by the body and brain is reduced which will result in changes in metabolism in the brain. Metabolic changes in the brain can affect changes in the number and function of cells in the brain, so that the brain will experience changes in normal function. Another negative impact caused by iron deficiency anemia is that the body's immune system decreases, causing the body to be susceptible to disease, as well as decreased intellectual performance. ${ }^{34}$

Low iron status can be influenced by several factors, namely, lack of consumption of animal food sources as a source of easily absorbed iron (heme iron), while plant foods (non-heme iron) are a source of iron that is high but difficult to absorb. so it takes a large portion to meet the needs of iron in a day. It can also be caused by a lack of nutrients that play a role in iron absorption, such as protein and vitamin $\mathrm{C}$. Consumption of foods high in fiber, tannins and phytates can inhibit iron absorption. ${ }^{37}$

\section{Stages of Iron Deficiency}

Based on the stages of iron deficiency, the highest number of students in the non-irondeficient category are $11(44 \%)$ and the highest stage is in stage 1 as many as 10 people (40\%). This shows that based on the stage of iron deficiency, the most iron deficiency is in stage 1 (Iron Depletion) in students at SMPN 39 Kerinci Regency, Jambi Province in 2020. In line with Junengsih's research (2017), students' iron stages are at stage 1, which is $83.7 \% .{ }^{47}$ and research (Diajeng, et al, 2018) as many as 59 female students $(95.1 \%)$ with no iron deficiency. ${ }^{52}$

Iron is the most abundant micro mineral in the human and animal bodies, which is 3 to 5 grams in the adult body. Inadequate iron intake means less oxygen is delivered to the tissues. As a result, people quickly feel tired, lethargic and unable to concentrate properly. Based on the $2013 \mathrm{RDA}$, the recommended iron intake is $26 \mathrm{mg} / \mathrm{day} .^{48}$ Iron deficiency anemia in school children is an unresolved health problem because its prevalence is more than the national standard, which is $>20 \% .{ }^{49}$

The most iron deficiency stages are in stage 1 . The first stage is iron deficiency (iron depletion). In general, at this stage there are no symptoms, at this stage the supply of iron in the bone marrow is reduced. Serum ferritin will decrease resulting in 
increased absorption of iron by the intestinal mucosa as compensation the liver will slowly synthesize more transferrin so that there will be an increase in TIBC causing a second stage of iron deficiency (limited iron erythropoiesis). This situation does not cause anemia (normal CBC) and normal erythrocyte morphology, red blood cell distribution is usually still normal. ${ }^{50}$

\section{Nutritional Status}

Based on the research, the results were obtained from 25 respondents, the most with poor nutritional status, namely 16 people $(64.0 \%)$ in students at SMPN 39 Kerinci Regency Jambi Province in 2020.

The results of this study are in line with previous research conducted by Azis, (2018), it is found that the most students have malnutrition $(67.2 \%) .^{32}$ and Damanik's research, (2019) also obtained the nutritional status of the most undernourished respondents $(76.2 \%){ }^{53}$

Nutritional status is the state of a person's body as an accumulation of food consumption so far (Rokhmat, et al., 2016). Nutritional status in children is influenced by direct factors, namely diet and indirect factors, namely economic conditions. Knowledge of nutrition has an important role in the formation of a person's diet because it can influence a person in choosing the type and amount of food consumed. Someone who is based on good nutritional knowledge will pay attention to the nutritional state of every food he consumes. Nutritious food is not an expensive and delicious food (Taiyeb, Mushawwir, et al., 2016). ${ }^{38,39}$

School children breakfast is the most important thing in activities to improve nutritional status, in addition to lunch and dinner activities. Good nutritional intake is in accordance with the General Guidelines for Balanced Nutrition (PUGS). However, school-age children are very less able to consume vegetables and fruit (Utari, et al., 2016). Another factor that can influence is the intake of snacks consumed at rest also does not meet the macronutrient needs of the respondents, such as crackers, sweets, and other factory snacks. Most snacks are not only empty of calories, but also contain very few nutrients, besides that they can interfere with appetite (Reppi, et al., 2015). ${ }^{40.41}$

\section{Relationship between Nutritional Status and Iron Status}

5813
Based on the research, it was found that respondents with more or less nutritional status had iron deficiency without anemia $(90.9 \%)$ and normal nutritional status had the least iron deficiency $(63.6 \%)$. The results of the statistical test (chi-square) obtained a value of $\mathrm{p}=0.029(\mathrm{p}$ $<0.05$ ), it can be concluded that there is an association between nutritional status and iron status in students of SMPN 39 Kerinci Regency, Jambi Province in 2020.

The results of this study are in line with research previously conducted by Triwinarni, (2017). The results showed that there was an association between nutritional status and iron status with $\mathrm{p}=$ 0.01 . These results are also in line with research conducted by Naristasari, (2015) which states that there is an association between nutritional status (BMI) and iron status in class XI students in three high schools in Yogyakarta City. ${ }^{42,43}$

Nutrients which, if inadequate intake can lead to iron deficiency in the body. Iron intake plays a role in the formation of red blood cells. Inadequate iron intake will increase iron absorption from food, mobilize iron stores in the body, reduce iron transport to the bone marrow, and reduce hemoglobin levels, resulting in anemia. $^{44}$

A nutrient that plays a role in increasing the absorption of iron in the small intestine is vitamin C. Absorption of non-heme iron increases fourfold when vitamin $C$ is present because the function of vitamin $\mathrm{C}$ is to transfer iron from transferrin in the plasma to ferritin in the liver. Thus, vitamin C indirectly has a role in hemoglobin levels. ${ }^{45}$

\section{CONCLUSION:}

Based on the results of research on the relationship between nutritional status and iron status in students of SMPN 39, Kerinci Regency, Jambi Province in 2020, it can be concluded that:

1. The most age is 12.0-12.11 years.

2. Most gender is female.

3. The most common stages of iron deficiency are non-iron deficiency.

4. Iron status was in the same category as noniron deficiency and iron deficiency without anemia.

5. The most nutritional status is undernutrition.

6. There is a relationship between nutritional status and iron status in students of SMPN 39, Kerinci Regency, Jambi Province in 2020. 


\section{REFERENCES}

[1] Program N, Iii SD, Stikes K, Jambi B. Pencegahan Anemia Pada Remaja Putri Di Pondok Pesantren Darussalam Al-Hafidz Kota Jambi. J Abdimas Kesehat. 2019;1(2).

[2] Nuraeni R, Sari P, Martini N, Astuti S, Rahmiati L. Peningkatan Kadar Hemoglobin melalui Pemeriksaan dan Pemberian Tablet Fe Terhadap Remaja yang Mengalami Anemia Melalui "Gerakan Jumat Pintar." $J$ Pengabdi Kpd Masy (Indonesian J Community Engag. 2019;5(2):200.

[3] Ozdemir N. Iron deficiency anemia from diagnosis to treatment in children. Turk Pediatr Ars. 2015;50(1):11-1.

[4] Istiqomah D.Hubungan Pola Makan Dengan Kejadian Anemia Pada Remaja Putri Di SMA Negeri 2 Pringsewu Tahun 2016. J Ilm Kesehat. 2016;5(10).

[5] Romandani QF, Rahmawati T. Hubungan Pengetahuan Anemia dengan Kebiasaan Makan pada Remaja Putri di SMPN 237 Jakarta. J Persat Perawat Nas Indones. 2020;4(3):193.

[6] Susilowati E, Rahmawati EQ, Dharma AK, Kediri H. Pengaruh Status Gizi Terhadap Potensi Intelektual Anak Usia Sekolah Bina Insani Lirboyo Kediri. VOL 4.; 2020.

[7] Istiqomah D. Hubungan Pola Makan Dengan Kejadian Anemia Pada Remaja Putri Di SMA Negeri 2 Pringsewu Tahun 2016. J Ilm Kesehat. 2016;5(10).

[8] Wahyu Mahar Permatasari N. Hubungan Antara Status Gizi Dengan Siklus Dan Lama Menstruasi Dengan Kejadian Anemia Remaja Putri Di SMA Negeri 3 Surabaya. 2016. http://lib.uniar.ac.id. Accessed September 3, 2020.

[9] Wicaksono RB. Sistem Pakar Mengidentifikasi Gizi Buruk Pada Anak Menggunakan Metode Antropometri Berbaasis Web. December 2015.

[10] Pasalina PE, Jurnalis YD, Ariadi A. Hubungan Indeks Massa Tubuh Dengan Kejadian Anemia Pada Wanita Usia Subur PRANIKAH. J Ilmu Keperawatan dan Kebidanan. 2019;10:2.

[11] Simbolon D. Model Prediksi Indeks Massa Tubuh Remaja Berdasarkan Riwayat Lahir dan Status Gizi Anak. Kesmas Natl Public Heal J. 2013;8(1):19.
[12] Kementrian Kesehatan. 2012. Laporan Riset Kesehatan Dasar (Riskesdas) Bidang Biomedis. Jakarta : Badan Litbangkes, Kemenkes RI: 2015

[13] Bambang Permono, Sutaryo, IDG. Ugrasena, Endang Windiastuti, Maria Abdulsalam. 2012. Buku Ajar HematologiOnkologi Anak. ed 4. Jakarta:IDAI

[14] Siti Setiati, Idrus Alwi, Aru W. Sudoyo, Marcellus Simadibrata K, Bambang Setiyohadi, Ari Fahrial Syam. 2014. Buku Ajar Ilmu Penyakit Dalam. ed 6. Jakarta:Interna Publishing

[15] Rahmah Hida Nurrizka. 2019. Buku Kesehatan Ibu Dan Anak Upaya Kesehatan Masyarakat Konsep Dan Aplikasi. Depok:PT RajaGrafindo Persada

[16] Richard N M, Vinay Kumar, Abul K Abbas, Nelson Faution. 2016. Buku Saku Dasar Patologis Penyakit ed 7. Jakarta:EGC

[17] Maharani S. Penyuluhan tentang Anemia pada Remaja. $J$ Abdimas Kesehat. 2020;2(1):1.

[18] Aru W.Sudoyo, Bambang Setiyohadi, Idrus Alwi, Marcellus Simadibrata K, Siti Setiati. 2009. Buku Ajar Ilmu Penyakit dalam ed 5. Jakarta:Interna Publishing

[19] Dr. Luh seri Ani.2014. Buku Saku Anemia Defisiensi Besi Masa Prahamil \& Hamil. Jakarta:ECG

[20] Jimenez K, Kulnigg-Dabsch S, Gasche C. Management of iron deficiency Anemia. Gastroenterol Hepatol. 2015;11(4):241-50.

[21] Fahdina Luthfiana -. Hubungan Pengetahuan Dan Kepatuhan Konsumsi Tablet Besi Dengan Kejadian Anemia Pada Remaja Putri di SMP Negeri 24 Tangerang Tahun 2019. July 2019. http://repository.upnvj.ac.id/. Accessed August 2, 2020.

[22] Indartanti D, Kartini A. Hubungan Status Gizi Dengan Kejadian Anemia Pada Remaja Putri Usia 12-14 Tahun. 2014.

[23] Adiyani K, Heriyani F, Rosida L. Hubungan Status Gizi Dengan Kejadian Anemia Pada Remaja Putri Di SMA PGRI 4 BANJARMASIN. Vol 1.; 2020. http://ppjp.ulm.ac.id/journals/index.php/hms /article/view/459. Accessed September 6, 2020.

[24] dr. Aaltje E. Manampiring, M. Kes. Prevalensi Anemia Dan Tingkat Kecukupan 
Zat Besi Pada Anak Sekolah Dasar Didesa Minaesa Kecamatan Wori Kabupaten Minahasa Utara. 2014;14-8.

[25] Alda Veronica Panjaitan. Gambaran Asupan Energi, Protein, Zat Besi, Dan Status Gizi Pada Remaja Di SMP Advent Lubuk Pakam. 2019;35-6.

[26] Ageng Siti Zaenab. Perbedaan Status Anemia Berdasarkan Konsumsi Zat Besi (Fe) Dan Lama Menstruasi Pada Siswi SMK Negeri 1 Tabanan. 2020;20-1

[27] Is susiloningtyas. Pemberian Zat Besi (Fe) Dalam Kehamilan. Universitas Islam Sultan Agung Semarang 2020;4,5.

[28] Kementrian Sosial Republik Indonesia. Data Kependudukan Desa Pondok Pulau Sangkar Kecamatan Bukit Kerman Kabupaten Kerinci Provinsi Jambi. 2020

[29] Yuli Suryanti, Indramien Netty A, Suryani, Indah Minfadlillah. Hubungan Pengetahuan Dan Pola Makan Dengan Kejadian Anemia Pada Remaja Putri Di MTs Swasta AlHidayah Talang Bakung Kota Jambi Tahun 2017;184-5

[30] Putri Azzahroh, Foppy Rozalia. Faktorfaktor Yang Berhubungan Dengan Kejadian Anemia Pada Remaja Putri Di SMAN 2 Kota Jambi Tahun 2018;6805-7

[31] 31 Safitri, Sri Maharani. Hubungan Pengetahuan dengan Kejadian Anemia Pada Remaja Putri Di SMPN 13 Kota Jambi Tahun 2019;262-4.

[32] Azis AA, Pagarra H, Asriani. Hubungan Asupan Zat Gizi dan Status Gizi dengan Hasil Belajar IPA Siswa Pesantren MTs di Kabupaten Buru. J IPA Terpadu. 2018;1(2):50-6.

[33] Syahfitri Y, Ernalia Y, Restuastut T. Gambaran Status Gizi Siswa-Siswi Smp Negeri 13 Pekanbaru Tahun 2016. J online Mhs Fak Kedokt [Internet]. 2017;4(9):1689-99. Available from: https://www.neliti.com/publications/184062 /gambaran-status-gizi-siswa-siswi-smpnegeri-13-pekanbaru-tahun-2016

[34] Desiawan A. Hubungan Asupan Zat Besi (Fe) Dan Status Gizi Dengan Prestasi Belajar Siswa Sekolah Dasar Di Sd Negeri Kudu 02 Kecamatan Baki Kabupaten Sukoharjo. 2015.
[35] Tiastuti SE. Hubungan Status Zat Besi, Vitamin $C$ dan Status Gizi dengan Kadar Hemoglobin pada Remaja Putri Kelas X di SMA Negeri 1 Teras Kabupaten Boyolali. 2016;1-11.

[36] Kusudaryati Hubungan Usia, Asupan Vitamin C Dan Status Zat Besi Dengan Kadar Hemoglobin Pada Remaja Putri Anemia. 2018.

[37] Indarti, Dea dan Kartini, Apoina. 2014. Hubungan Status Gizi dengan Kejadian Anemia Pada Remaja Putri di SMP Negeri 9 Semarang.

[38] Rokhmat,F., Muniroh, L., Nindya, T. 2016. Hubungan Tingkat kecukupan energi dan zat gizi makro dengan status gizi siswi SMA di Pondok pesantren Al-Izzah Kota batu. Jurnal Media Gizi Indonesia, Vol.11, No.1 Januari-Juni 2016; hlm. 94-100. Surabaya: Departemen Gizi Kesehatan Fakultas Kesehatan masyarakat Universitas Airlangga.

[39] Taiyeb, A., Azis, A., \& Handayani, L. 2016. Hubungan Pengetahuan Gizi dengan Pola Makan Melalui Penerapan Modul Gizi. Prosiding Seminar Nasional Biologi 2016. ISBN 978-682-721198-3-6. Jurusan Biologi FMIPA Universitas Negeri Makassar

[40] Utari, L., Ernalia, Y. \& Suyanto. 2016. Gambaran Status Gizi dan Asupan Zat Gizi pada Siswa Sekolah Dasar Kecamatan Sungai Sembilan Kota Dumai. JOM FK Volume 3 No.1 Februari 2016.

[41] Reppi, B., Kapantow, N.H., \& Punuh, M.I. (2015). Hubungan Antara Asupan Energi dengan Status Gizi Siswi SMA Negeri 4 Manado. Jurnal KESMAS Universitas Sam Ratulangi, Vol. 3, No. 1. Diakses dari http://jkesmasfkm.unsrat.ac.id

[42] Triwinarni C, Hartini TNS, Susilo J. Hubungan Status Gizi dengan Status Zat Besi pada Siswi SMA di Kecamatan Pakem. J Nutr. 2017;19(1):61-7.

[43] Naristasari, AA. 2015. Hubungan Status Gizi dengan Status Zat Besi pada Siswi Kelas XI di Tiga SMA di Yogyakarta. Naskah Publikasi. Diakses pada tanggal 3 Mei 2016 di opac.unisayogya.ac.id/318/1/

[44] Fatimah, ST. (2011). Pola Konsumsi Ibu Hamil Dan Hubungannya Dengan Kejadian Anemia Defisiensi Besi. J. Sains \& Teknologi. Vol. 7 No. $3: 137-152$ 
[45] Ourkesh M, Sadri I, Sahranavand A, Ojagil A, Dehyanpoori M. 2011. The Effects Of Two Different Dose of Antioxidant Vitamin C Supplementation on Bioenergetics Index in Male College Student. Journal of American Science (6): 852-858.

[46] Junengsih, Yuliasari (2017). Hubungan Status Zat Besi dengan Kejadian Anemia pada Remaja Putri SMU 98 di Jakarta $\begin{array}{lllll}\text { Timur.(online) } & \text { vol. } & 5 & \text { No } & 1\end{array}$ (http://ejurnal.poltekkesjakarta3.ac.id)

[47] Kemenkes R. Riset Kesehatan Dasar. Jakarta; 2013.

[48] Riset Kesehatan Dasar. Badan Penelitian dan Pengembangan Kesehatan Kementrian Kesehatan Republik Indonesia.2014

[49] Kurniati. Anemia Defisiensi Zat Besi (Fe). Fakultas Kedokteran, Universitas Lampung. 2020

[50] Sofiatun, Gambaran Status Gizi, Asupan Zat Gizi Makro, Aktivitas Fisik, Pengetahuandan Praktik Gizi Seimbang Pada Remaja Di Pulau Barrang Lompo Makassar. Universitas Hasanuddin Makassar. 2017.

[51] Diajeng Dian, dkk. 2018. Hubungan Asupan Protein Dan Kebiasaan Makan Pagi Terhadap Kadar Hemoglobin Pada Anak Usia 9-15 Tahun Di Tambaklorok Semarang Utara.

[52] Damanik. Gambaran IMT/U, Status Zat Besi (Fe), dan Inhibitor Zat Besi (Fe) Dengan Anemia Remaja Putri Di SMA Muhammadiyah 7 Sawangan, Depok. Universitas Pembangunan Nasional "Veteran" Jakarta. 2019. 